\title{
Association between the C3435T single-nucleotide polymorphism of multidrug resistance 1 gene and risk of gastric cancer
}

\author{
JULIANA OLIVEIRA, ALEDSON V. FELIPE, PAULA Y.J. CHANG, CELIA A.M. PIMENTA, \\ TIAGO D. SILVA, JOÃO MASSUD and NORA M. FORONES
}

Oncology Group, Gastroenterology Division, Federal University of Sao Paolo, SP, Brazil

Received February 1, 2012; Accepted May 15, 2012

DOI: $10.3892 / \mathrm{mmr} .2012 .926$

\begin{abstract}
The multidrug resistance 1 (MDRI) gene encodes P-glycoprotein, which confers resistance to antineoplastic drugs, but also affects the kinetic disposition of certain drugs and carcinogens. The C3435T polymorphism of the MDRI gene may influence the transport and excretion of carcinogens, increasing the risk of cancer. The aim of this study was to evaluate the association between this polymorphism and the risk of gastric cancer (GC). Ninety-eight patients with non-cardia GC and 203 healthy subjects participated in the study. DNA was extracted from leukocytes and the MDRl polymorphism was analyzed using PCR-RFLP. Serology was performed by ELISA for the investigation of infection with Helicobacter pylori. No significant difference in the genotype $(\mathrm{p}=0.668)$ or allele $(\mathrm{p}=0.745$ ) frequency of the $\mathrm{C} 3435 \mathrm{~T}$ polymorphism was observed between the GC and control groups. There was no association between the genotypes studied and the risk of GC in patients infected with $H$. pylori $(\mathrm{p}=0.662)$. Patient survival was not correlated with the genotypes studied $(\mathrm{p}=0.454)$. No correlation was observed between the C3435T polymorphism of the MDRl gene and GC risk or prognosis in the population studied.
\end{abstract}

\section{Introduction}

Gastric cancer (GC) is the fourth most common type of cancer in the world and the second leading cause of death due to cancer. In general, the incidence of GC is two to three times higher in developing countries and the disease is more frequent

Correspondence to: Dr Aledson V. Felipe, Disciplina de Gastroenterologia, Universidade Federal de Sao Paulo, R. Botucatu 740, $2^{\circ}$ andar, São Paulo, CEP: 04023900, Brazil

E-mail: aledson.felipe@gmail.com

Abbreviations: CG, gastric cancer; P-gp, P-glycoprotein; SNP, single-nucleotide polymorphism; MDR1, multidrug resistance 1; PCR, polymerase chain reaction; RFLP, restriction fragment length polymorphism; dNTP, deoxynucleotide triphosphate

Key words: polymorphism, gastric cancer, multidrug resistance 1 among men than women (1-4). Gastric carcinogenesis is a multifactorial process involving endogenous and exogenous factors that cause genetic mutations. GC comprises different stages, such as superficial gastritis, atrophic gastritis, intestinal metaplasia, dysplasia and, finally, carcinoma (5). In addition to infection with Helicobacter pylori, epidemiological studies have demonstrated the importance of environmental factors, such as consumption of salty, canned and smoked foods for the genesis of GC (6).

$\mathrm{P}$-glycoprotein (P-gp) is encoded by the multidrug resistance $1(M D R 1)$ gene and confers resistance to multiple antineoplastic agents. In addition, this protein affects the kinetic disposition of certain drugs and carcinogens (7). Various isoforms of P-gp are known, which are classified into classes I, II and III. Classes I and II are related to multidrug resistance, whereas class III is involved in the transport of phospholipids $(8,9)$. Although first detected in tumor cells, $\mathrm{P}$-gp is also expressed in normal tissues. In the gastrointestinal tract, $\mathrm{P}-\mathrm{gp}$ is the first defense of the body against oral exposure to drugs and toxins (10). $\mathrm{P}$-gp is a membrane-bound transporter that was first identified to be responsible for the development of multidrug resistance (7). This glycoprotein acts as an ATP-dependent efflux pump that exports drugs, reducing the intercellular concentrations of different chemotherapeutic agents. P-gp shows an expression gradient in gastrointestinal epithelial cells, with this protein being more expressed in the apical region. However, it is also found in hepatic canaliculi and in the proximal tubules of the kidneys, where it contributes to the excretion of biliary and urinary products, respectively (10-13).

There is growing evidence that changes in the function and/or expression of the $M D R l$ gene contribute to the pathogenesis of inflammatory diseases of the gastrointestinal tract (14). Researchers have demonstrated that a polymorphism in the C3435T region of the MDRl gene influences the development of different cancers, since it is directly related to the transport of potentially carcinogenic substances (15-19). Although there are several reports on the pharmacological and enzymatic action of P-gp, studies investigating the association of the MDRl gene polymorphism and GC are scarce. Therefore, the aim of the present study was to characterize the genotypic profile of this genetic polymorphism and to correlate this polymorphism with the risk of GC and tumor aggressiveness. 


\section{Patients and methods}

Sample population. A case-control study was conducted. The case group consisted of patients with GC seen at the outpatient clinic of the Discipline of Clinical Gastroenterology, Federal University of Sao Paulo-Escola Paulista de Medicina, Brazil. Patients with a confirmed histological diagnosis of non-cardia adenocarcinoma were invited to participate in the study. The control group consisted of healthy subjects who attended the blood collection service of the Central Laboratory of the Sao Paulo Hospital. The study was approved by the Ethics Committee of the institution, and all patients signed an informed consent form.

Assay methods. An ELISA kit (R-Biopharm GmbH, Germany) was used for the detection of serum anti-H. pylori IgG antibodies. DNA was extracted from peripheral venous blood leukocytes collected with EDTA as an anticoagulant using the Blood Spin Mini kit (Invisorb, Germany). The samples were submitted to polymerase chain reaction (PCR) and then genotyped using the PCR-restriction fragment length polymorphism (RFLP) technique. The following primers were used: forward 5'-TGC TGG TCC TGA AGT TGA TCT GTG AAC-3' and reverse 5'-ACA TTA GGC AGT GAC TCG ATG AAG GCA-3'. The reaction mixture for PCR contained $40 \mathrm{ng}$ DNA, $1 \mathrm{X}$ reagent buffer, $0.125 \mathrm{mmol} / \mathrm{l}$ of each deoxynucleotide triphosphate (dNTP), $1.5 \mathrm{mmol} / \mathrm{l}$ $\mathrm{MgCl}_{2}, 0.75 \mu \mathrm{mol} / 1$ of each primer and 0.5 units Platinum Taq DNA polymerase in a final volume of $10 \mu 1$. DNA was denatured at $94^{\circ} \mathrm{C}$ for $2 \mathrm{~min}$, followed by 35 cycles at $94^{\circ} \mathrm{C}$ for $30 \mathrm{sec}, 60^{\circ} \mathrm{C}$ for $30 \mathrm{sec}$ and $72^{\circ} \mathrm{C}$ for $30 \mathrm{sec}$, with a final extension at $72^{\circ} \mathrm{C}$ for $4 \mathrm{~min}$. After amplification, the products were digested with 5 units of the restriction enzyme $\mathrm{MboI}$ (New England Biolabs) at $37^{\circ} \mathrm{C}$ for $3 \mathrm{~h}$ and the fragments were visualized on $3 \%$ agarose gel stained with ethidium bromide. Genome sequencing was used to confirm the PCR and RFLP techniques using random samples of the two groups. The PCR product of the MDRl gene was purified using the Big Dye XTerminator kit (Applied Biosystems) and sequenced in an ABI Prism 3100 sequencer (Applied Biosystems). The reverse primer was used for sequencing. The electropherogram was analyzed with the Sequence Scanner v1.0 program.

Statistical analyses. The Statistical Package for the Social Sciences v19.0 was used for statistical analysis. Age was compared between groups by the Student's t-test. The Chi-square test was used to determine differences in genotypes and alleles between the two groups. Survival was estimated by the Kaplan-Meier method and survival curves were compared by the log-rank test.

\section{Results}

The case group consisted of 98 patients with GC, including 43 (43.9\%) women. The control group consisted of 203 subjects, including $110(54.2 \%)$ women. The patients of the case and control groups were admitted during the same period. There was no difference in gender $(\mathrm{p}=0.12)$ or age $(\mathrm{p}=0.125)$ between the two groups (Table I).
Table I. Characteristics of the patients with gastric cancer and controls.

\begin{tabular}{lrrr}
\hline & $\begin{array}{c}\text { Control } \\
\mathrm{n}=203(\%)\end{array}$ & $\begin{array}{c}\text { Cancer } \\
\mathrm{n}=98(\%)\end{array}$ & $\mathrm{p}^{- \text {value }^{\mathrm{a}}}$ \\
\hline $\begin{array}{l}\text { Gender } \\
\text { Female }\end{array}$ & $110(54.2)$ & $43(43.9)$ & 0.120 \\
$\begin{array}{l}\text { Male } \\
\text { Age (years) } \\
\text { Mean } \pm \text { SD }\end{array}$ & $63(45.8)$ & $55(56.1)$ & \\
& $63.2 \pm 12.2$ & $60.4 \pm 12.4$ & 0.125 \\
${ }^{\mathrm{a}} \chi^{2}$-test. & & & \\
\hline
\end{tabular}

Specific primers were used for the amplification of a DNA fragment of the MDRI gene polymorphism, which resulted in a product of $248 \mathrm{bp}$. Digestion of the amplicon with $\mathrm{MboI}$ produced four bands of 232, 172, 60 and 16 bp in patients carrying the heterozygous CT genotype, two bands of 232 and $16 \mathrm{bp}$ in patients with the homozygous mutant TT genotype and three bands of 232,172 and $16 \mathrm{bp}$ in patients carrying the homozygous CC genotype (Fig. 1).

In the control population, the genotypes were in HardyWeinberg equilibrium and the frequency of TT, CC and CT genotypes was $19.2,33.0$ and $47.8 \%$, respectively. In patients with GC, the frequency of TT, CC and CT genotypes was 15.3, 32.7 and $52.0 \%$, respectively. Genotype analysis showed no difference in genotype frequencies between patients with GC and controls $(\mathrm{p}=0.668)$. Similarly, no significant difference in the frequency of the $\mathrm{C}$ and $\mathrm{T}$ alleles was observed between patients with GC and healthy controls $(\mathrm{p}=0.745)$ (Table II). Comparison of genotypes between patients with metastatic (stage IV) and non-metastatic GC (stages I, II and III) showed no significant difference $(\mathrm{p}=0.257)$.

The number of subjects infected with $H$. pylori was similar in the two groups (GC: $\mathrm{n}=43,43.9 \%$; control: $\mathrm{n}=111$, $54.7 \%)(\mathrm{p}=0.160)$. No significant difference in CC, TT and CT genotype frequencies was observed between patients with GC $(\mathrm{p}=0.662)$ or controls $(\mathrm{p}=0.399)$ infected or not with H. pylori (Table III). There was no difference in survival between the genotypes studied ( $\mathrm{p}=0.454)$ (Fig. 2).

\section{Discussion}

According to the Brazilian National Cancer Institute (INCA) (1), GC was the most frequently diagnosed cancer among men $(64.3 \%)$ in 2010 , with a higher incidence of the disease in men and women above the age of 50. A higher prevalence of GC among men (56.1\%) was also observed in the present study. The mean age of the patients was 60.2 years. Studying cases of acute leukemia in India, Rao et al (20) observed a higher percentage of the TT genotype (51.7\%) among patients with acute lymphoid leukemia (ALL) when compared to the control group (28.9\%). However, no association was observed for patients with acute myeloid leukemia. In that study, the CC genotype was associated with a poorer prognosis of ALL. By contrast, Jamroziak et al (21) found a higher frequency of the CT genotype (48\%) in Polish patients with ALL, but the differ- 


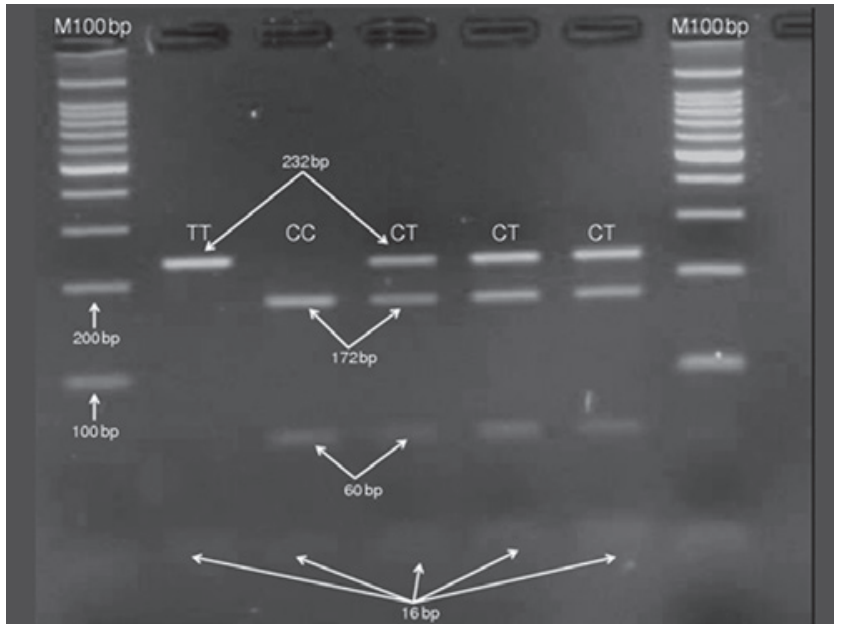

Figure 1. Detection of the length of polymorphisms by PCR followed by agarose gel electrophoresis. Wild-type CC genotype showing three fragments (172, 60 and $16 \mathrm{bp}$ ); homozygous mutant TT genotype showing two fragments (232 and $16 \mathrm{bp}$ ) and heterozygous CT genotype showing four fragments $(232,172,60$ and $16 \mathrm{bp})$.

ence was not significant. A higher frequency of the T allele and $\mathrm{CT}$ genotype has been observed in Iranian breast cancer patients when compared to a group without cancer, but the difference was not significant (18). The C3435T polymorphism of the MDRI gene has been investigated in inflammatory diseases, such as peptic ulcer, and in cancer, but the results are contradictory. In intestinal inflammatory disease, Schwab et al (22) found a higher frequency of the T allele and TT genotype of the MDRl gene in German patients with ulcerative colitis, but not in patients with Crohn's disease when compared to healthy subjects. Tahara et al (17) showed that the TT genotype of the MDRl gene was associated with a reduced risk of GC in the Japanese population. The authors also investigated the effect of the MDRl polymorphism on the risk of GC in patients infected or not with H.pylori and found that patients carrying the TT genotype had a lower risk of the disease, irrespective of the presence or absence of $H$. pylori infection (17). Also in Japan, Sugimoto et al (16) demonstrated a higher incidence of the CT genotype in patients with GC, gastric and duodenal ulcer and gastritis, but the difference was not significant when compared to the control group. The homozygous TT genotype was found to be associated with a higher risk of GC in an Iranian population when compared to a control group (23). Comparison of the frequencies of the $\mathrm{C}$ and $\mathrm{T}$ alleles between patients with GC and controls showed a higher prevalence of the $\mathrm{C}$ allele in the two groups (58.7 and $56.9 \%$, respectively), but the difference was not significant. CT genotype was the most frequent in both the control group and the case group (47.2 and $52 \%$, respectively), but the finding was again not statistically significant. Balram et al (24) compared the frequency of the $\mathrm{C}$ allele among Asian, European and African populations and found a mean frequency of $43 \%$ in the Asian population, $52 \%$ in European Caucasians and 78\% in Africans. In the present study, the frequency of the $\mathrm{C}$ allele was $56.9 \%$ in the control group and $58.7 \%$ in patients with GC, values similar to those reported for European Caucasians.

Gastric carcinogenesis is a multifactorial process and infection with $H$. pylori is one of the risk factors $(5,6)$. In
Table II. Genotype and allele frequency in patients with gastric cancer and controls.

\begin{tabular}{lrrr}
\hline & $\begin{array}{c}\text { Control } \\
\mathrm{n}=203(\%)\end{array}$ & $\begin{array}{c}\text { Cancer } \\
\mathrm{n}=98(\%)\end{array}$ & p-value $^{\mathrm{a}}$ \\
\hline Genotype & & & 0.668 \\
TT & $39(19.2)$ & $15(15.3)$ & \\
CC & $67(33.0)$ & $32(32.7)$ & \\
CT & $97(47.8)$ & $51(52.0)$ & \\
Allele & & & 0.745 \\
T & $175(43.1)$ & $81(41.3)$ & \\
C & $231(56.9)$ & $115(58.7)$ & \\
\hline
\end{tabular}

${ }^{\mathrm{a}}$ Fisher's exact test and $\chi^{2}$-test.

Table III. Frequency of the MDR1 polymorphism in patients with gastric cancer and controls infected or not with Helicobacter pylori.

\begin{tabular}{lcccc}
\hline & $\begin{array}{c}\mathrm{CC} \\
\mathrm{n}(\%)\end{array}$ & $\begin{array}{c}\mathrm{TT} \\
\mathrm{n}(\%)\end{array}$ & $\begin{array}{c}\mathrm{CT} \\
\mathrm{n}(\%)\end{array}$ & $\mathrm{p}^{- \text {value }^{\mathrm{a}}}$ \\
\hline Cancer & & & & 0.662 \\
$\begin{array}{l}\text { H.pylori-positive } \\
\text { H.pylori-negative }\end{array}$ & $5(5.1)$ & $15(10.3)$ & $23(23.5)$ & \\
Control & & & & 0.399 \\
$\begin{array}{l}\text { H.pylori-positive } \\
\text { H.pylori-negative }\end{array}$ & $18(10.3)$ & $41(20.2)$ & $49(24.1)$ & \\
\hline
\end{tabular}

${ }^{2} \chi^{2}$-test.

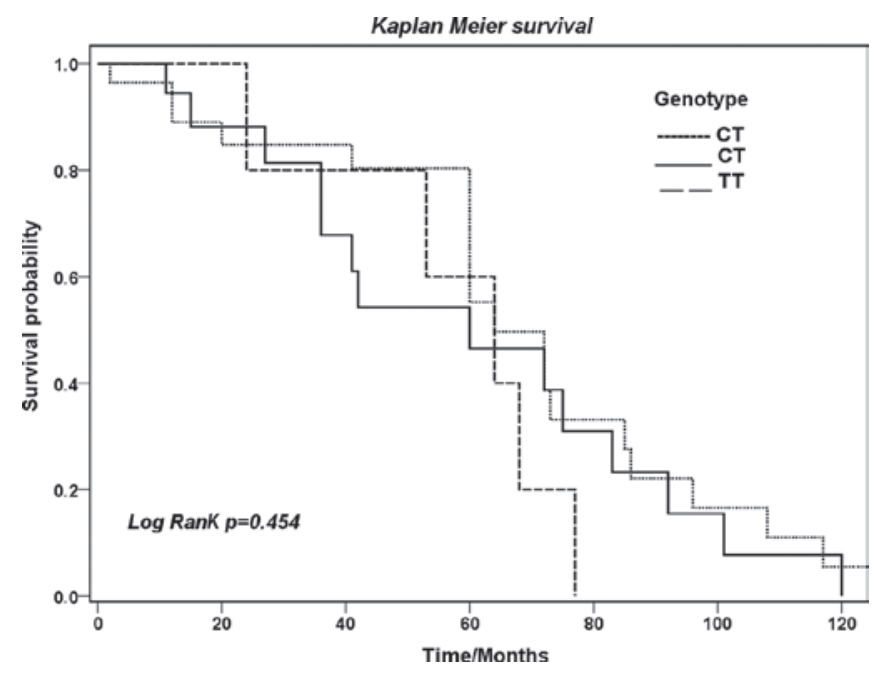

Figure 2. Kaplan-Meier curves of the presence of the C3435T polymorphism in overall survival ( $\mathrm{p}=0.454$, log-rank test) among $\mathrm{GC}$ patients, where the $\mathrm{C} / \mathrm{T}, \mathrm{T} / \mathrm{T}$ and $\mathrm{C} / \mathrm{C}$ genotypes are combined. Log-rank test was based on the full data of GC patients.

Japan, Sugimoto et al (17) found no association between the MDRI C3435T polymorphism and the risk of GC in patients infected with $H$. pylori or in patients with peptic ulcer. In 
the present study, we also observed no difference between genotypes, infection with $H$. pylori and GC risk. The results suggest that $H$. pylori infection is not associated with the MDR1 C3435T polymorphism. Patients with advanced-stage GC had poor survival ( $\mathrm{p}=0.003$ ). However, no difference in survival was observed between the genotypes studied. Although MDR1 T-55C and BCRP C43A were reported to be functional SNPs that change their protein functions $(25,26)$, the C3435T SNPs analyzed in this study had no association with overall survival. This suggests that this gene is probably not the most important determinant in survival analysis. However, it is also possible that the limited number of SNPs selected for this study missed the most important functional variants of this gene. Further investigation is required to illustrate how these genes may affect the clinical outcome of GC. The differences in the results of studies investigating the MDR1 C3435T polymorphism may be related to differences in the ethnic background of the populations studied and in the number of patients included in each study. In addition, the MDR1 C3435T SNP is located in a non-coding region and therefore may not interfere with the expression of P-gp (23), a fact explaining the lack of association between this polymorphism and gastric carcinogenesis.

In conclusion, the present results provide evidence that the C3435T polymorphism of the MDRI gene is not associated with susceptibility to gastric cancer. No correlation was observed between this polymorphism and infection with H. pylori or survival.

\section{Acknowledgements}

This study was generously funded by The Sao Paulo Research Foundation (FAPESP).

\section{References}

1. Instituto Nacional de Câncer - INCA. Brasília: Ministério da Saúde. Estimativa 2012: Incidência de Câncer no Brasil. Available at: http://www.inca.gov.br/estimativa/2012/estimative 20122111.pdf

2. Matysiak-Budnika T and Mégraudb F: H. pylori infection and gastric cancer. Eur J Cancer 42: 708-716, 2006.

3. Wen S and Moss SF: H. pylori virulence factors in gastric carcinogenesis. Cancer Lett 282: 1-8, 2009.

4. Ferlay J, Autier P, Boniol M, Heanue M, Colombet M and Boyle P: Estimates of the cancer incidence and mortality in Europe in 2006. Ann Oncol 18: 581-592, 2007.

5. Correa P and Houghton J: Carcinogenesis of Helicobacter pylori. Gastroenterology 133: 659-672, 2007.

6. Shin CM, Kim N, Lee HS, Lee DH, Kim JS, Jung HC and Song IS: Intrafamilial aggregation of gastric cancer: a comprehensive approach including environmental factors, Helicobacter pylori virulence, and genetic susceptibility. Eur J Gastroenterol Hepatol 23: 411-417, 2011.

7. Ueda K, Cornwell MM, Gottesman MM, Pastan I, Roninson IB, Ling V and Riordan JR: The MDR1 gene, responsible for multidrug-resistance, codes for P-glycoprotein. Biochem Biophys Res Commun 141: 956-962, 1986.
8. van Helvoort A, Smith AJ, Sprong H, Fritzsche I, Schinkel AH, Borst P and van Meer G: MDR1 P-glycoprotein is a lipid translocase of broad specificity, while MDR3 P-glycoprotein specifically translocates phosphatidylcholine. Cell 87: 507-517, 1996.

9. Dey S: Single nucleotide polymorphisms in human P-glycoprotein: its impact on drug delivery and disposition. Expert Opin Drug Deliv 3: 23-35, 2006.

10. Thörn M, Finnström N, Lundgren S, Rane A and Lööf L: Cytochromes P450 and MDR1 mRNA expression along the human gastrointestinal tract. Br J Clin Pharmacol 60: 54-60, 2005.

11. Willingham MC, Cornwell MM, Cardarelli CO, Gottesman MM and Pastan I: Single cell analysis of daunomycin uptake and efflux in multidrug-resistant and -sensitive KB cells: effects of verapamil and other drugs. Cancer Res 46: 5941-9546, 1986.

12. Thiebaut F, Tsuruo T, Hamada H, Gottesman MM, Pastan I and Willingham MC: Cellular localisation of the multidrugresistance gene product P-glycoprotein in normal human tissues. Proc Natl Acad Sci USA 84: 7735-7738, 1987.

13. Jäeger W: Classical resistance mechanisms. Int J Clin Pharmacol Ther 47: 46-48, 2009.

14. Ho GT, Moodie FM and Satsangi J: Multidrug resistance 1 gene (Pglycoprotein170): an important determinant in gastrointestinal disease? Gut 52: 759-766, 2003

15. Paule B, Castagne V, Picard V, Saffroy R, Adam R, Guettier C, Farinotti R and Bonhomme-Faivre L: MDR1 polymorphism role in patients treated with cetuximab and irinotecan in refractory colorectal cancer. Med Oncol 27: 1066-1072, 2010.

16. Sugimoto M, Furuta T, Shirai N, et al: MDR1 C3435T polymorphism has no influence on developing Helicobacter pylori infection-related gastric cancer and peptic ulcer in Japanese. Life Sci 83: 301-304, 2008.

17. Tahara T, Arisawa T, Shibata T, Hirata I and Nakano H: Multi-drug resistance 1 polymorphism is associated with reduced risk of gastric cancer in the Japanese population. J Gastroenterol Hepatol 22: 1678-1682, 2007.

18. Taheri M, Mahjoubi F and Omranipour R: Effect of MDR1 polymorphism on multidrug resistance expression in breast cancer patients. Genet Mol Res 9: 34-40, 2010.

19. Turgut S, Turgut G and Atalay EO: Genotype and allele frequency of human multidrug resistance (MDR1) gene C3435T polymorphism in Denizli province of Turkey. Mol Biol Rep 33: 295-300, 2006.

20. Rao DN, C Anuradha, Vishnupriya S, Sailaja K, Surekha D, Raghunadharao D and Rajappa S: Association of an MDR1 gene (C3435T) polymorphism with acute leukemia in India. Asian Pac J Cancer Prev 11: 1063-1066, 2010.

21. Jamroziak K, Balcerczak E, Cebula B, et al: Multi-drug transporter MDR1 gene polymorphism and prognosis in adult acute lymphoblastic leukemia. Pharmacol Rep 57: 882-888, 2005.

22. Schwab M, Schaeffeler E, Marx C, et al: Association between the C3435T MDR1 gene polymorphism and susceptibility for ulcerative colitis. Gastroenterology 124: 26-33, 2003.

23. Sabahi Z, Salek R, Heravi RE, et al: Association of gastric cancer incidence with MDR1 gene polymorphism in an ethnic Iranian population. Indian J Cancer 47: 317-321, 2010.

24. Balram C, Sharma A, Sivathasen C and Lee EJ: Frequency of C3435T single nucleotide MDR1 genetic polymorphism in an Asia population: phenotypic-genotypic correlates. Br J Clin Pharmacol 56: 78-83, 2003.

25. Kimchi-Sarfaty C, Oh JM, Kim IW, Sauna ZE, Calcagno AM, Ambudkar SV and Gottesman MM: A 'silent' polymorphism in the MDR1 gene changes substrate specificity. Science 315: 525-528, 2007.

26. Mizuarai S, Aozasa N and Kotani H: Single nucleotide polymorphisms result in impaired membrane localization and reduced atpase activity in multidrug transporter ABCG2: Int J Cancer 109: 238-246, 2004. 